\title{
How Does Ocha Attend Her Lectures? Lessons Learnt From an Adult Learner With a Cinderella Complex
}

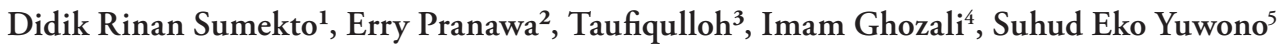

\footnotetext{
1 Sarjanawiyata Tamansiswa University, Directorate of Postgraduate in Education, English Education Department, Jl. Kusumanegara No.157, Yogyakarta, ID - 55165 Daerah Istimewa Yogyakarta, Indonesia, didikrinan@ustjogja.ac.id

2 Widya Dharma University, Indonesian Education Department, Jl. Ki Hajar Dewantara, Klaten Utara, ID - 57438, Klaten, Jawa Tengah, Indonesia, erry@unwidha.ac.id

3 Pancasakti University, English Education Department, Jl. Halmahera KM. 1, Tegal, ID - 52121, Jawa Tengah, Indonesia, taufiqkayla@upstegal.ac.id

4 Sarjanawiyata Tamansiswa University, Directorate of Postgraduate in Education, English Education Department, Jl. Kusumanegara No.157, Yogyakarta, ID - 55165 Daerah Istimewa Yogyakarta, Indonesia, ghozali@ustjogja.ac.id

5 Widya Dharma University, English Education Department, Jl. Ki Hajar Dewantara, Klaten Utara, ID - 57438, Klaten, Jawa Tengah, Indonesia, yuwono@unwidha.ac.id
}

Annotation. This study investigates an undergraduate student with her Cinderella complex. Observation and videotape were undertaken from her agentive interactions and lectures as a single case study with the iterative and unstructured model analysis. The findings showed Ocha's high motivation during attending her speaking classes, although her pronunciation, fluency, grammar, and vocabulary were still unsatisfactory. Ocha's behaviors looked different from others regarding her lack of interactions with others, ignorance, introversion, egocentrics, dependence, and reticence.

Keywords: agentive interaction, cinderella complex, contextual performance.

\section{Introduction}

Creating harmonious classroom in college's lecturing activities has been taking on lecturer's priority to all students' learning collaboration, responsibility, respectfulness, communication, problem-solving, cognitive and affective orientation, etc. Both processes 
and outputs need consistent and sustainable maintenance to enable higher education students to find and synchronize the essence of those lecturing activities day-to-day. Hence, education for all or inclusive education will be representing the purpose of harmonious classroom creation, although all lecturers fully realize that this expectation still complies with some barriers and compromises with the eligible solutions. Hegde and Bishop (2020) regard this situation to be one of the education design objectives for higher education students that relies on suitable problem-solving in contemporary social phenomena. The pedagogical issues in language teaching have engaged lecturers in their mainstreaming, both cognitive and affective domains to accomplish higher education students' necessities (Sumekto \& Setyawati, 2020).

Students' educational backgrounds diversity is also relatively concerned with universal openness. In this case, the lecturer's approval deals with some instructional and pedagogical affairs. This approval aligns and decorates the classroom's learning activities that lead to the classroom mainstream (Sumekto et al., 2020). Therefore, the communicative approach shall reflect students' real necessities. Beneath this approach, multiple tasks can be addressed to obtain designated purposes (Liu et al., 2020). A well-structured decision-making process is manageable to indicate the external resources and devote students' minds for supervisory multiple tasks and designated outputs (Castello-Tarrida et al., 2019), besides students' self-esteem will refer to an overall evaluation upon their worth as individuals, capabilities, and general admiration on self-acceptance and -respect for their goodness (Helmi et al., 2019). Unfortunately, the communicative approach is not as smooth as we are simply thinking in its implementation. So far, students' learning conditions become the subsets of learning problems in both academic and non-academic clusters. For example, students with limited oral proficiency will have barriers to comprehending what is spoken by others. Moreover, students with learning limitations commonly characterize their real learning conditions. This can happen in terms of students' difficulties in keeping and maintaining awareness when speaking with, aborting spoken information, following collective instructions, and comprehending the spoken information (Victoria State Government, 2019).

The experiential problems relating to students' different behaviors with readability inclass participation are stricken in the classroom environment, in which both lecturer and other classmates need the perseverance to face and adapt these problems professionally. Empirically, this study portrays the third-semester female student who becomes a single case study on her Cinderella complex background when attending the English lectures. So far, the Cinderella complex at most became popular when Colette Dowling wrote 'The Cinderella Complex: Women's hidden fear of independence' (Dowling, 1981; Xu et al., 2019). Dowling established that this complex expands the psychological and physical differences in women and expresses indirectly (Xu et al., 2019; Chastine \& Darmasetiawan, 2019), in which they will be expecting heroic figures who can protect them from solving problems. Cinderella complex initially appeared when women were still their childhoods. They are 
not well-prepared to be tough and independent and dominantly tend to be non-assertive and dependent on others. They conditionally grow up with some dependencies and spoils since the authoritative, authoritarian, permissive-indulgent, and permissive-neglectful factors become her fruitful influence (Oktinisa et al., 2017), as well as always look for protections and show the blue devils.

Joys, laughs, smiles, and other happy facial expressions are conditions that can be created by lecturers and students in classroom circumstances. These conditions show how all members in the classroom adapt to the learning comfortableness, as well as their pedagogical purposes (Jakonen \& Evnitskaya, 2020). Proving the pedagogical expectation, a lecturer is aware to be open-minded towards instructing in his or her inclusive classes and adapting lecturing courses and methods to recover disabled students' necessities (Otanjac, 2016). Besides intimating the mutual relationships may examine the dynamics of the developmental outcomes and well-being (Dalla et al., 2010) in a longer period that involve lecturer and students. These relationships become the substantial determinants for engaging academic and affective development as well as working boundaries that will be equally good and accommodative for both lecturer and students (Zarra, 2016). Identifying mechanisms, actions, and behavior may trigger students to acquire learning enactment that links learning strategy and students' mental capacity (Suwanarak, 2019) towards the explicit attitudes that permit students' reflections (Krischler \& Cate, 2020).

Another important issue relating to the pedagogical expectation highlights the cognitive contribution that establishes human minds regarding students' maturation, encouragement, anxiety, language performance, and learning strategy to differentiate the language learning effects (Jafari et al., 2020). When the pedagogical expectation addresses students' awareness for learning sustainability, the activities shall promote both inputs and outputs of learning, and increase participation in terms of learning existences (European Commission/EACEA/Eurydice, 2015). The interaction between lecturer and students shall decorate the class' creations and re-creations daily. At this point, communication transfers values and norms from one to another to gain newly adaptable learning environments and to attain consequences and systems of thinking (Alhassan et al., 2020). To prove the harmonious classroom creation, the classroom environment shall be enthusiastic, dynamic, and humble. All students respect and support each other, in which they gain a stake in the success of managing the classroom (Pagliaro, 2011).

Some studies reported students' learning disabilities regarding the influence of its affective factors on their learning performances. Arini (2019) firstly turned out that the Cinderella complex relied on woman's behaviours refusing social responsibilities and commitment in interpersonal relationships, where this complex happened during her early adulthoods conforming all about self-responsibilities. The complex was remarkably documented that its symptom was due to central nervous system dysfunction that possibly occurred across the women's life span, whilst self-regulatory behaviours, self-esteem, social perception, interaction (Illinois Community College Board, 2014), and direct and 
indirect relationships intrinsically (Sanford, 2015) became the contributing factors towards this complex. Therefore, to be accordant with the socio-emotional fastidiousness for higher education students, the tagline of learning makes me happy led to the highest position that reflected students' learning progress (Lin, 2020). Secondly, students' achievement motives were hierarchically constituted with their self-efficacy and willingness which directly conveyed their speaking frequency (Turner et al., 2021), although few students still faced main barriers to focus on the linguistic features (Reyes, 2015). Hence, the frequent speaking opportunities needed to focus on students' knowledge delivery to convey the substantial meanings (Hosni, 2014). On the other hand, students' poor inputs in speaking performance led to problems that ultimately contributed to the socio-cultural and interpersonal contexts (Gan, 2012). Of all these studies, the psychological problems, such as anxiousness, solicitude for being faults, and lack of confidence became the primary factors for English-speaking barriers (Shen \& Chiu, 2019).

Moving forward into an investigation on a third-semester female English education student, named Ocha (pseudonym) with her Cinderella complex, this study focuses on her agentive interactions and contextual performances in online and offline environments in terms of empirically being granted from her successes when attending my speaking class. Therefore, this study pointedly proposes a single research question, as follows: How do Ocha's problems appear with her agentive interactions and contextual performances during attending speaking class? Referring to the above research questions, the objective of this study aims at investigating a third-semester female undergraduate English education student whose personal background was experientially indicative of having a Cinderella complex. Herein, Ocha's performance in the classroom constitutes her academic and affective successes when attending speaking class.

\section{Methods}

This study used a single case study that designed the information synthesis (Gablinske, 2014) to me as respondent's former speaking III lecturer. This study brought about a female English education student to be a single respondent. As confirmed in this study, Ocha, the pseudonym from which I filed her e-mail address, was a 22-year-old undergraduate student at the English Education Department, Widya Dharma University, Klaten, Indonesia. Ocha was currently a third-semester student and sit in my former speaking class. She came from a middle-class family, whose parents deserved their professional careers as teachers at the upper secondary schools in Klaten District. Her parents graduated from the undergraduate degrees and lived in Klaten District, Jawa Tengah as well. Ocha also lived with her male sibling at her parents' house. Apart from Ocha's personal life, Ocha was psychologically diagnosed to suffer from a Cinderella complex, who felt a fear of being independent and was portrayed with the unconscious desires granted by others 
(Dowling, 1981; Xu et al., 2019), touched with the dependency factors, focused more on other unrealistic expectations, caused conditional disappointments (Heriyati, 2011), and be characterized as a "never-growing" adult woman since she struck barriers in social and professional relationships (Kalkan et al., 2019).

This study procedurally engaged an undergraduate student from the English education department as a single case study design towards the insightful qualitative interpretation. The research procedure primarily referred to the series of speaking activities for the third-semester commencement in the academic year of 2020-2021 through the flexibly blended-learning platforms during the Covid-19 pandemic-online and offline meetings since my former small class merely had seventeen students. My class was scheduled to have an 8-meeting with other two additional meetings in two credit system on speaking III class. This class was handled by two lecturers as a team-teaching subject. Accordingly, the natural teaching and learning processes kept engaging in the teaching syllabus for all English education students inclusively.

Data collection used Ocha's speaking performance and in-depth interview to yield detailed and comprehensive academic and affective results, including actions, behaviors, and interactions to obtain the naturalistic settings qualitatively. Data were recorded from the noticeably videotape-recorder and some were documented by smartphone's WhatsApp application. Before commencing the recorded interview with Ocha, I noticed her on 14th December 2020 that the interview would be recorded for the research purpose only. She could understand and gave me permission to record the interview and use her picture. Ocha experientially regularly joined my former speaking class just like her other sixteen classmates. Herein, Ocha's speaking performance and my in-depth interview with her were importantly set to fulfill the primary data in this study. On the other hand, I used to keep closer with her since my academic analysis concluded that she needed a pay particular attention during attending her lectures in the running semester.

This case study data were assorted regarding Ocha's agentive interaction and contextual performance in attending her English lectures. Hence, data analysis exposed its iterative and unstructured model that emphasized description [describing and inevitably treating the data], analysis [examining relationships processes, factors, and linkages across the data points], and interpretation [explaining the data beyond the data points and analysis] (Reeves et al., 2013), whilst the procedure of analyzing the data carried out from the insightful interpretations that were accordingly undertaken form the basis of the intercourse between Ocha's academic and affective contributions when attending her speaking III class. 


\section{Results}

First of all, this early analysis attempted to describe and treat the data inevitably towards Ocha's observable personality in her lectures' awareness and improvement. My first academic contact with Ocha happened last year when she was still in the firstsemester student of the English Education Department, where I devoted myself as one of the English lecturers for eleven years and five months. Ocha sat in my speaking class last year. The class went in the regular "rhythms" till I later realized that there was something that happened with her. Frankly speaking, I did truly mistake about Ocha's background or I might be incompetent in providing my remarkable conclusion about Ocha. Pointedly, she was different from her other classmates in terms of significantly affective conditions. However, time flew away and Ocha kept attending her English classes till the third semester. In the third semester, Ocha attended my speaking III class through the academic year of 2020-2021. She attended my regular class just like her other sixteen classmates on September $16^{\text {th }}, 2020$. Any additional information I gained from Ocha's chat relying on her residence that took around 10 miles far heading to campus. Ocha also confessed that she could not independently ride a motorbike, therefore Ocha's father always took her to the campus and picked her up home every day. This became a normal moment when Ocha did it with her father, although she thought that someday she will be riding a motorbike independently.

From my previous academic communications and relationships with her in the third semester, Ocha was different from her other classmates in the classroom in terms of showing academic and affective skills during attending my speaking classes. My class attendance lists surprisingly recorded that Ocha wholeheartedly always attended her lectures without being absent. Ocha surprisingly attracted my attention since she was never absent in her entire lectures during the third semester. When attending her lectures, she always sat in the front row by herself. Nevertheless, I never asked her why she always sat alone in the first row. I experientially confessed that Ocha's sitting position was very rare done by my other students in my classes. They randomly used to sit down in the second, third, or back row. Experiencing this condition, I also never put it into my great deal as long as they remained participating in the lecturing processes. My speaking III class initially began with 'the introduction on speaking', which attempted to mainly introduce the teaching syllabus, teaching methods, and assessment approaches throughout the semester as well as lightly address students' previous learning experiences in the second semester. Ocha kept following, listening, and telling a bit to talk about the session. But she was emotionally still far from deserving herself to be an adult learner.

Despite Ocha's lack of impressive performance, something imprinted me that she was a consistent student attending every lecture based on the schedules. Attempting to resolve my curiosity, I afforded to meet her personally for an interview. Ocha's confession turned out that one of her high school class teachers had ever asked and coached her regarding 
her personality, although Ocha did not specifically tell me in a comprehensive talk since she was rather difficult to react with my questions. She hardly talked in a clear tone during my ten minutes and fifty-nine seconds interview with her. Beyond this condition, the most emphatic aspect arising from the obtainable data relied on her introversive personality in which Ocha had stumbled on her weak quality of communication processes. Fortunately, Ocha's consistent commitment to attending her speaking classes motivated her to increase her English knowledge, although she preferred to enjoy learning Japanese.

Students' assignment in my speaking III class was notified through speaking's teaching syllabus and be part of students' performance. The topic relied on students' talk on the current issues. Third-semester students were required to perform their speaking skills, including Ocha. They performed and finalized their assignment with the videotaped recording and submitted it through the Google Drive file. In this case, Ocha's speaking assignment expressed her online learning experience during the Covid-19 pandemic, which was recorded by her smartphone on December $16^{\text {th }}, 2020$. Ocha began with her greetings by conveying 'Hello', then followed by mentioning her name, 'my name is Ocha' (Pseudonym). She kept expressing a few words with her hesitation and fillers before continuing the talk of online learning. Ocha continued to express her ideas on how students and lecturers decided to have their online learning for the first time. She truly seemed to understand the situation in which the Covid-19 pandemic made online learning became available. Based on her experience, Ocha afforded her study either with the lecturers or classmates using the learning platforms, such as Google Classroom, Meet, and Zoom. But Ocha confessed that she never experienced learning with Edmodo before.

Ocha also realized having problems with online learning since her internet connection had a bad signal and her internet quota was limited. Anyhow, she attempted to find out the closest spot where the internet signal supported her connection. Overall, Ocha wholly understood the designated topic-students' talk on the current issues. She could explain the issues relating to the learning platforms applying for Google Classroom, Meet, Zoom, and Edmodo, and identified problems regarding the internet signal with her basic performance. However, Ocha's basic performance was still stuck by some speechless in two till five minutes, confused expression, and unclear and nervous voice. Figure 1 showed Ocha's originally videotaped performance which was set with ELAN Linguistic Annotator 5.9 and the script was recorded due to the importance of analytic assessment.

"Hello, my name is Ocha (Pseudonym). Today I have [Hesitation] talking to the talking about [Filler] learning online to [Filler] pandemic Covid-19. It's begin when all the staff on my campus announced to have activity in [Speechless in three seconds] from home. Beside this, all the student and lecturers to do learning online. I think I used [Filler] all the [Speechless in two seconds] the online application like a Google Classroom, Meet or Zoom. [Filler] Edmodo at [Speechless in four seconds] is, I usen't [Confusion] to. I never used [Filler] Edmodo... if done. Beside the learning online, I have a benefit or the problems about this learning online. Well, for the Google Classroom [Speechless in three seconds] well for Google Classroom [Hesitation], I can accept, attach or the [Confusion] can be committed 
everyone by via chat. But I have a problem about the Meet or the Zoom. I have a problem because my connection has low or it be called the quota is [Filler] low. So, I [Speechless in five seconds] find the ... I find the location to get [Filler] bit connection to learning online. And lastly, I have to learning online with a good connection. That's all my opinion for the learning [Unclear and nervous voice] learning online and see you next time".

The next analysis recorded the contribution of Ocha's speaking performance following her analytically descriptive assessment. Being part of the analytic assessment, Ocha's comprehensive speaking performance was empirically relevant with the observable and analyzed pronunciation, fluency, grammar, vocabulary criteria. A well-understandable explanatory speaking generally started from the greetings at the first time till she ended with the closing statement. As found in Ocha's speaking III performance, her pronunciation had very limited control of phonological features and was frequently unable to comprehend, whilst her fluency corresponded with the remarkable difficulties in maintaining simple exchanges, unclear and nervous voice, and voiceless in considerable seconds. Ocha's fluency was frequently stuck with her hesitation, pause, and filling in the gaps with e and em.

This study also analyzed Ocha's mobility relating to her initiatives texting me through WhatsApp on December 16th, 2020 at 19:17. Her text informed me that she just sent the Google Drive link for her videotaped recording on the speaking III assignment. Then, she texted me, "This is my new google drive link, sir". Fortunately, the link could be opened just before she was failed to send me the former file through the Google Drive link. After appreciating her submission, I ended my chat. Unfortunately, what surprised me was that Ocha texted me again on January 13th, 2021 at 08:49 a.m., admitting to me that she did not belong to any group members for the speaking III final examination. She wrote me, "Sorry Sir, I don't have a group for final [the final] test because [because is omitted] for last Tuesday, I didn't confirm that. Also, I don't have quota [a quota] for inform [informing] me". So far, her cell phone quota would be always Ocha's reasoning to excuse her from neglecting the important matters relating to her online and offline learning processes.

Further, once upon a time in speaking III class discussion, Ocha ignored to join in her other classmates' group for unrealistic and unacceptable reasons. To the best of my knowledge, I asked her to join the group two times, whilst I kept sharing my focus for other students in groups. But Ocha replied to my order by saying, "But, I don't have quota [a quota], Sir". Nevertheless, I gently insisted Ocha joined. She finally joined her group and blessedly one of her female counterparts was willing to tether her cell phone quota with Ocha. Continuing my chat with Ocha via WhatsApp, I asked her to see me on Thursday, 14 January 2021 at 09:00 a.m. at my office for passing her final examination, but the plan did not run smoothly. Then, I offered her to see me at noon instead of 09:00 a.m. But Ocha seemed to ignore my text and replied, "Yes, after my friends finished their examination. But I want to go home now". Realizing this situation, it became clearer that Ocha also had a problem with her awareness of learning necessities. 


\section{Figure 1}

\section{Ocha's Originally Video-Taped Speaking Performance}

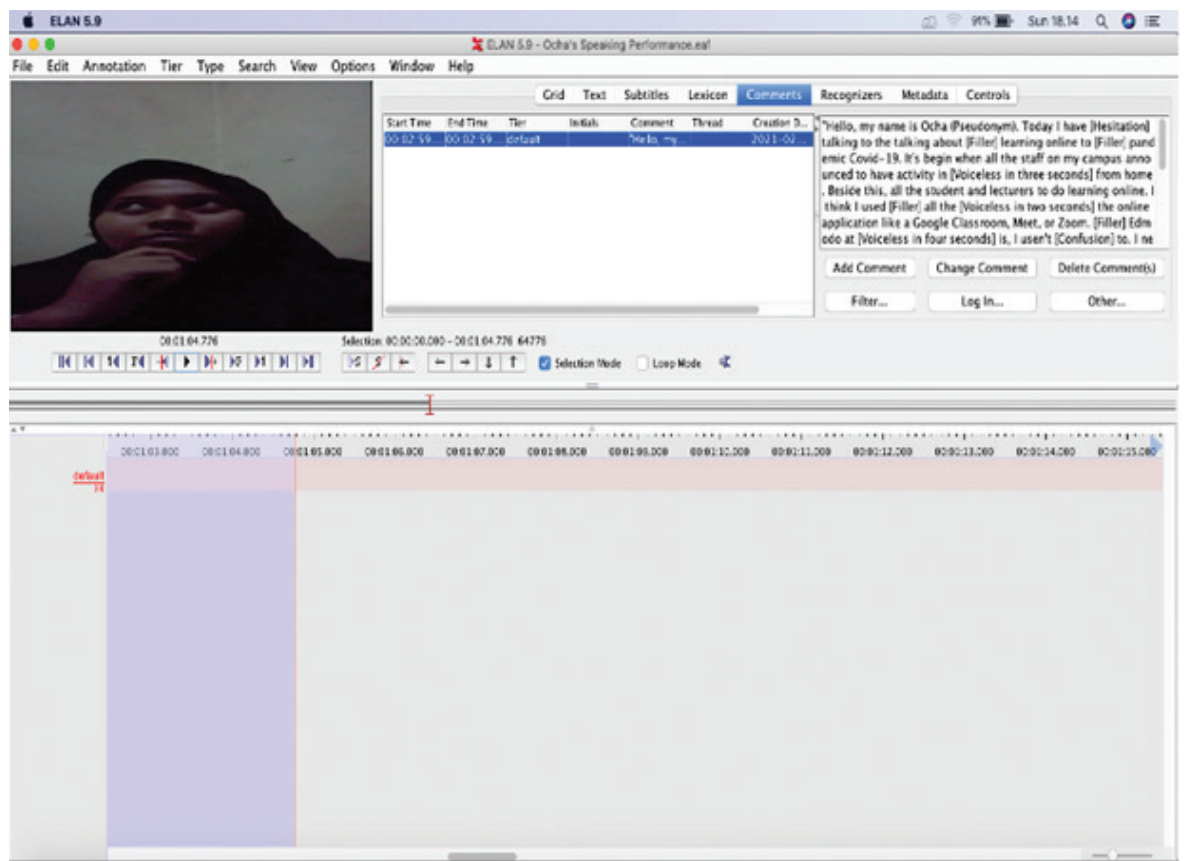

Note. Ocha's analytically descriptive assessment on speaking was recorded through the ELAN. The observable analysis recorded her pronunciation, fluency, grammar, and vocabulary skills. However, Ocha's consent upon my interview with her and her image capture was eligible due to the research purpose only, dated 14th December 2020.

Based on the above analyses and referenced discussions, Ocha's originally recorded script on her online learning perspectives would be appropriately corrected and replaced in this format, as follows:

"Hello, my name is Ocha (Pseudonym). Today I am talking about online learning in the Covid-19 pandemic. It begins when the staff on my campus announce to have all activities at home. Besides that, all students and lecturers also do the same way. When learning online, I use some online applications, like Google Classroom, Meet, and Zoom. Meanwhile, I never use Edmodo for my online learning. However, I have some benefits and problems when learning with these applications. For example, when I use Google Classroom, I can do some chats with others, while I cannot use it on a video platform. I also have another problem when using Google Meet and Zoom since my internet connection is low and I have a limited quota for internet access. So, I shall find the location to get a good internet connection. Lastly, I need to have a steady connection to my online learning purposes. That's all my opinion for online learning, see you next time, and thank you". 


\section{Discussion}

First thing first, this discussion relied on the use of an analytically descriptive assessment that promoted students' speaking skills. The assessment accomplished students' pedagogical knowledge and learning strategy integrating the substantial qualities, such as accommodating speaking levels in the beginner (A1), elementary (A2), intermediate (B1), upper-intermediate (B2), advanced (C1), and proficient (C2), as well as measuring students' maturation and humanized teaching approaches to students with Cinderella complex. In Ocha's case, the analytic assessment would be remarkably eligible since this assessment accommodated her speaking skills through the measurable criteria. Notwithstanding the analytic assessment of oral proficiency previously entertained any considerable advantages, but it was more time-consuming and tedious since the assessors manifested the results for multifarious portions (Aleksandrzak, 2011; Saritha, 2016; Shatrova et al., 2017), prepared apparent and unambiguous interpretations for each criterion (Llach, 2011), and could be equally applicable (Namaziandost \& Ahmadi, 2019). Accordingly, it happened with awareness of social relationships triggering the meaningful processes (Lahcen, 2014). That was why, social interaction was a basic way to Ocha's mental well-establishment dealt with her common interest, innermost thoughts, and feelings (Edmonds \& Beardon, 2008), as well as her maturation who became one of the most diagnostic individual distinguishability (Kuklewicz \& King, 2018) when participating in her classes. The gestural expressions also became Ocha's assistive communication when she attempted to understand my instructions, although sometimes I orally needed to repeat two to three times to attract Ocha's attention. However, the symbolic gestures became Ocha's well-identified communication in day-to-day lecture sessions (Sumekto et al., 2021).

Being her former lecturer, I was personally aware of Ocha's generic skills that could be identifiable to be her learning outcomes which supported the information handling, learning management, effective communication, computer literacy, critical thinking, and problem-solving (McLean et al., 2012). In this case, an important point to engage Ocha in learning barriers, I eagerly proposed myself to put on Ocha's thinking priority that dealt with other classmates' thinking and working collaboratively in the classes. My priority aimed at motivating Ocha and her classmates to give respect to each other, share equal ideas, and allow them to explore some relevant and challenging issues to gain justifiable goals among my students. In this respect, El-Koumy (2016) established that creating and appreciating students' self-esteem and self-confidence successes for every achievable student's input and output day-to-day would be the priority.

Ocha's grammar and vocabulary showed merely limited control of a few grammatical forms, used the vocabulary of covert words and phrases (Cambridge English Qualifications, 2008). Grammar aspects should be effectively formatted from the simple to the complex constructions, showing indication of subject-predicate agreement, tenses, word 
orders, articles, pronouns, and prepositions (Pappamihiel et al., 2012). Overall, Ocha's grammar and vocabulary were dominantly found in a critical revision. Additionally, what happened in both criteria relied on weak and mismatched vocabulary with the task and frequent grammatical errors in simple structures were obscured. Ocha's learning disabilities might truly prevent her academic failures by obtaining the inclusive learning circumstances that provided challenges effectively (Artiles \& Ortiz, 2002). Her learning disabilities required modeling of cognitive processes through the learning strategies effectively to obtain her ineffective learning processes and employed with a purposeful methodology (El-Koumy, 2016). Ocha's low self-esteem and motivation, and her high anxiety faced deep barriers in speaking skills, despite potentially obtaining comprehensible linguistic competencies (Leong \& Ahmadi, 2017). Unfortunately, having experiences with low self-esteem for longer periods could either stimulate mental health problems, such as behavioral disorder, depression, or anxiety. Other learning difficulties might lead to being self-withdrawn, disengaged appearance, aggressive, rude, and disruptive as the consequence of being frustration since students were not available to maintain the learning management (Suldo et al., 2011; Howell 2009; Victoria State Government, 2019).

In any situation of facing the Cinderella complex, Ocha was not conservatively used to be plentiful enough with taking care of herself, holding up for herself, and affirming herself (Saha \& Safri, 2016). This situation constituted with the locked-in and separation phase, where the locked-in phase triggered distinguishability of social and personal identity. The more significant distinguishability between social and personal identity, the more barriers will be triggered, whilst the separation phase was separately signed by personal relationships or partnerships in the classes. This situation seemed to be a vacuum identity as caused by her uncertainty inner and outer roles since the only motive dealt with running away from the problems (Arini, 2019). Further, Ocha's learning disabilities needed extra time to reply to responses or answers, since they arranged a temporary moment in their silence to manage their thoughts without providing them glimmers (Otanjac, 2016). Ocha's difficulties at most indicatively showed a specific language processing disorder, which impacted their skills development (Perras, 2014).

Therefore, the procedures of individual performance and development must be mindful on looking at Ocha's performance as the consequence of comprehensive interactions involving lecturer and other classmates (Klingner et al., 2006), although negative and positive effects on her English skills development were still conditionally attainable (Andrade, 2009). Ocha needed to engage in an additional amenity, such as small groups, extra times and practices, loaded-courses reduction, and occupiable classroom management (Otanjac, 2016). The additional amenities reflected Ocha's identity and sense of self-worth became progressively associated with her academic and affective successes (Suldo et al., 2011; Howell 2009; Victoria State Government, 2019) through the apprehensive communication to gain target language (Nakhalah, 2016). Hence, El-Koumy (2016) respectively emphasized this affective domain on addressing Ocha's attitudes, emotions, 
and motivations by managing a non-threatening and low anxiety classroom atmosphere and by absorbing her linguistic faults to discharge inconvenience from making mistakes.

In this case, Ocha's Cinderella complex accordingly influenced her academic and affective performance either in her English classes' individual or collaborative contributions, Burns and Joyce (1997; Lahcen, 2014) matched this situation with learner's reticence which involved cultural, linguistic, and affective factors (Figure 2). Empirically, Ocha's reticence refrained from conveying a decision or judgment immediately in any lecturing process. In this context, cultural factors dealt with Ocha's prior learning contributions consequently. Meanwhile, affective factors accomplished Ocha's traits-reservedness, shyness, and introversion, low, middle, and high motivation levels, self-esteem and self-perception, anxieties, and social experiences during attending her lectures.

\section{Figure 2}

Ocha's Experiential Learning Reticence

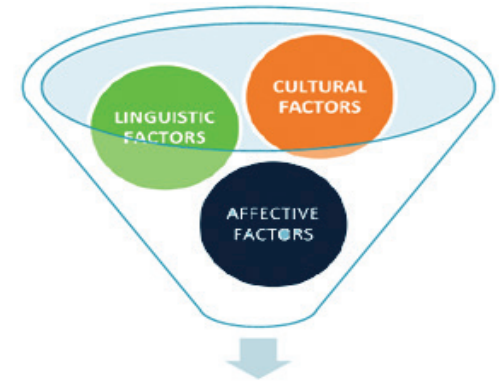

RETICENCE

Note. Ocha's reservedness, shyness, and introversion traits experientially distinguish her selfesteem, self-perception, anxieties, and social experiences during attending the lectures.

Casuistically Ocha's Cinderella complex relied on her reticence's cultural, linguistic, and affective factor, in which The National Education Association (2015) decided some efforts that might be suitably offered to create her lectures performance became more effective and progressive by maximizing a two-way communication, integrating awareness, advocating attitudes, and showing and caring with some applicably instructional strategies since she potentially had resilient survival skills to prove. Despite working on the above efforts, collaborations were either fundamental to stimulate better input and output learning development, to provide more effective teaching methodologies, more applicably effective pedagogy interventions, and more fruitful professional development programs shown by the lecturer (McCardle et al., 2005).

Supporting the above reticence in English lectures, definite behaviors and affinities became important to aid students' effective learning. In this casuistical experience, Ocha's confidence and motivation might meaningfully improve her English skills by keeping the 
continual adaptation in collaboration with other classmates and being open-minded. To prove Ocha's beneficial assistance, the capability of bringing about and processing the spoken information to derive meaningful contexts, such as skills on the understanding of verb agreement, prefixes, suffixes, and complex sentence construction, as well as to strengthen oral skills comprehension (Victoria State Government, 2019). The lecturing mainstreams were upon the priority to engage the student with learning difficulties in her behavioral and academic concerns (Logan, 2016). Last but not least, the instruction methods should objectively prioritize their comprehension through the underlyingly rooted processes and strategies (El-Koumy, 2016).

\section{Conclusions}

Ocha's problems in attending her speaking III class have empirically established that she is an adult learner with a Cinderella complex. Notwithstanding Ocha has a high motivation to attend her class without being absent, but she faces some difficulties in attending her learning activities either online or offline class-her limited oral proficiency, vocabulary, grammar, and pronunciation. Employing social relationships upon Ocha's lectures make her agentive interactions and contextual performances important to prioritize since she does not have significant interactions with her classmates both in offline and online classes that engage her in communicative and functional communication with others to create a conducive learning atmosphere. On the other hand, the findings merely reflect the subjective analyses and interpretations that potentially lead to some limitations upon an adult learner with Cinderella complex. Firstly, I realize that the limitation relies on the sample size and the environments from which data are collected through documentation and in-depth interview, and analyzed with the limited generalizability in this single case study. Pointedly, other respondents with the same personal backgrounds and environments, interview with Ocha's parents, high school teachers, and psychiatrist when exploring the locus of comparing the respondents are not eligible at this study. Secondly, despite contextualizing the data analyses and interpretations, some potential ambiguities accordingly relate to Ocha's Cinderella complex background applying for description, analysis, and interpretation approach may have better be acknowledged in other relevant researches in the future. Hence, recommendations upon this study are subject to other data collection methods which constitute the valid, measurable, tangible, trustworthy, and comparable instruments to reveal the novelties. The psychometric tests will be the reasonable options using the statistical analyses and experts' contents validation that will empirically enrich the results are remarkably suggested, although these recommendations are not generalizable. 


\section{References}

Aleksandrzak, M. (2011). Problems and challenges in teaching and learning speaking at advanced level. Glottodidactica. An International Journal of Applied Linguistics, 37, 37-48. https://doi. org/10.14746/gl.2011.37.3

Alhassan, A. -R. K., Abdulai, M \& Ibrahim, H. (2020). Communication and social interaction across cultures: The case of a German and Ghanaian educational exchange program. Journal of Intercultural Communication, 20(2), 1-15.

Andrade, M. S. (2009). The effects of English language proficiency on adjustment to university life. International Multilingual Research Journal, 3(1), 16-34. https://doi. org/10.1080/19313150802668249

Arini, D. P. (2019). Peterpan complex phenomenon: Self-identity crisis in forming intimation in adult man. Jurnal Psikodimensia, 18(2), 158-166. https://doi.org/10.24167/psidim.v18i2.2305

Artiles, A. J., \& Ortiz, A. A. (2002). English language learners with special education needs. Illinois: Center for Applied Linguistics and Delta Systems Co. https://files.eric.ed.gov/fulltext/ ED482995.pdf

Burns, A., \& Joyce, H. (1997). Focus on speaking. Sydney: National Centre for English Language Teaching and Research. https://is.muni.cz/th/zmjkc/THESIS Solcova text.pdf

Cambridge English Qualifications. (2008). Assessing speaking performance-Level A2. https:// www.cambridgeenglish.org/images/168617-assessing-speaking-performance-at-level-a2.pdf

Castello-Tarrida, A., Cladellas-Pros, R., \& Limonero-Garcia, J. T. (2019). The role of knowledge structures in adult excellence: An approach from expert functioning. Comunicar, 60(17), 49-57. https://doi.org/10.3916/C60-2019-05

Chastine, V., \& Darmasetiawan, N. K. (2019, March 4-6). Cinderella complex on working women [Conference presentation]. APA 2019 Convention, Manado, Sulawesi Utara, Indonesia. https:// www.atlantis-press.com/proceedings/insyma-19/55915436

Dalla, R. L., Marchetti, A. M., Sechrest, E. A., \& White, J. L. (2010). "All the men here have the peter pan complex-they don't want to grow up": Navajo adolescent mothers' intimate partner relationships-a 15-year perspective. Violence Against Women, 16(7), 743-763. https://doi. org/10.1177/1077801210374866

Dowling, C. (1981). The Cinderella complex: Women's hidden fear of independence. New York: Pocket Book.

Edmonds, G., \& Beardon, L. (2008). Asperger complex and social relationships: Adults speak out about asperger complex. In N. Shepherd. Social relationships and the communication problem (pp. 49-60). Jessica Kingsley Publishers.

El-Koumy, A. S. A. (2016). Teaching English as a foreign language to students with learning disabilities at the intermediate and advanced levels: A multiple-strategies approach. Cairo: Dar An-Nashr for Universities. https://files.eric.ed.gov/fulltext/ED568128.pdf

European Commission/EACEA/Eurydice. (2015). Adult education and training in Europe: Widening access to learning opportunities: Eurydice report. Brussels: Publications Office of the European Union. http://www.efad.org/media/1263/eurydice-report adult-educationand-training-i-europe 2015.pdf

Gablinske, P. B. (2014). A case study of student and teacher relationships and the effect on student learning. [Doctoral Dissertation], University of Rhode Island. http://digitalcommons.uri. edu/oa_diss/266 
Gan, Z. (2012). Understanding L2 speaking problems: Implications for ESL curriculum development in a teacher training institution in Hong Kong. Australian Journal of Teacher Education, 37(1), 43-59. https://doi.org/10.14221/ajte.2012v37n1.4

Hegde, A. L., \& Bishop, N. (2020). Simulation and reflective experience: An effective teaching strategy to sensitize interior design students to the visual needs of older adults. Art, Design \& Communication in Higher Education, 19(1), 33-49. https://doi.org/10.1386/adch 00012 _

Helmi, A. F., Widhiarso, W., Putri, A. K., Marvianto, R. D., Priwati, A. R., \& Shaleha, R. R. A. (2019). A model of online trust among adolescents. International Journal of Cyber Behavior, Psychology and Learning, 9(2), 34-50. https://doi.org/10.4018/IJCBPL.2019040103

Heriyati, N. (2011). Cinderella complex in Elizabeth Gilbert's eat pray love. Jurnal Ilmu Sastra, $6(1), 42-52$.

Hosni, S. A. (2014). Speaking difficulties encountered by young EFL learners. International Journal on Studies in English Language and Literature, 2(6), 22-30.

Howell, A. (2009). Flourishing: Achievement-related correlates of students' well-being. The Journal of Positive Psychology, 4(1), 1-13. https://doi.org/10.1080/17439760802043459

Illinois Community College Board. (2014). Guidelines for serving students with learning disabilities and other special learning needs. https://eric.ed.gov/?id=ED572253

Jafari, S., Jafari, S., \& Kafipour, R. (2020). How does she learn English? A case of a successful blind language learner. Vision: Journal for Language and Foreign Language Learning, 9(2), 131-142. https://doi.org/10.21580/vjv10i16727

Jakonen, T., \& Evnitskaya, N. (2020). Teacher smiles as an interactional and pedagogical resource in the classroom. Journal of Pragmatics, 163, 18-31. https://doi.org/10.1016/j.pragma.2020.04.005

Kalkan, M., Batık, M. V., Kaya, L., \& Turan, M. (2019). Peter Pan complex "men who don't grow": developing a scale. Men and Masculinities, 20(10), 1-13. https://doi. org/10.1177/1097184X19874854

Kargozari, H. R., Ghaemi, H., \& Heravi, M. A. (2012). Cohesive devices in argumentative, descriptive, and expository writing produced by Iranian EFL university students. Modern Journal of Language Teaching Methods, 2(3), 25-47.

Klingner, J. K., Artiles, A. J., \& Barletta, L. M. (2006). English language learners who struggle with reading language acquisition. Journal of Learning Disabilities, 39(2), 108-128. https:// doi.org/10.1177/00222194060390020101

Krischler, M., \& Cate, I. M. T. (2020). Inclusive education in Luxembourg: Implicit and explicit attitudes toward inclusion and students with special educational needs. International Journal of Inclusive Education, 24(6), 597-615. https://doi.org/10.1080/13603116.2018.1474954

Kuklewicz, A., \& King, J. (2018). "It's never too late”: A narrative inquiry of older Polish adults' English language learning experiences. The Electronic Journal for English as a Second Language, 22(3), 1-22.

Lahcen, A. (2014). Investigating speaking performance deficiency among learners of business English: The case of Master students at the Department of Commercial Sciences, University 
of Oran. [Master Thesis], Oran, Algeria. http://www.univ-oran2.dz/images/these memoires/ FLE/Magister/TMLE-29/Combinaison.pdf

Leong, L-. M., \& Ahmadi, S. M. (2017). An analysis of factors influencing learners' English speaking skill. International Journal of Research in English Education, 2(1), 34-41. https:// doi.org/10.18869/acadpub.ijree.2.1.34

Lin, Y-. Y. (2020). Support matters: Predictors of intrinsic motivation in older learners in Taiwan. Australian Journal of Adult Learning, 60(2), 190-212.

Liu, Z., Li, T., \& Diao, H. (2020). The influence of multi-assessment model on the motivation of adults' English listening and speaking learning. Theory and Practice in Language Studies, 10(9), 1086-1093.

Llach, M. (2011). Lexical errors and accuracy in foreign language writing. New York: Multilingual Matters. https://doi.org/10.21832/9781847694188

Logan, E. E. (2016). English language learners and learning disabilities. [Master Thesis], Hamline University, Minnesota, USA. https://digitalcommons.hamline.edu/cgi/viewcontent. cgi? article $=5103 \&$ context $=$ hse all

McCardle, P., Mele-McCarthy, J., Cutting, L., Kathleen Leos, K., \& D’Emilio, T. (2005). Learning disabilities in English language learners: Identifying the issues. Learning Disabilities Research \& Practice, 20(1), 1-5. https://doi.org/10.1111/j.1540-5826.2005.00114.x

McLean, M., Murdoch-Eaton, D., \& Shaban, S. (2012). Poor English language proficiency hinders generic skills development: A qualitative study of the perspectives of first-year medical students. Journal of Further and Higher Education, 37(4), 461-481. https://doi.org/10.1080/0 309877X.2011.645461

Nakhalah, A. M. M. A. (2016). Problems and difficulties of speaking that encounter English language students at Al Quds Open University. International Journal of Humanities and Social Science Invention, 5(12), 96-101.

Namaziandost, E., \& Ahmadi, S. (2019). The assessment of oral proficiency through holistic and analytic techniques of scoring: A comparative study. Applied Linguistics Research Journal, 3(2), 70-82. https://doi.org/10.14744/alrj.2019.83792

Oktinisa, T. F., Rinaldi, Hermaleni, T. (2017). Kecenderungan Cinderella complex pada mahasiswa perempuan ditinjau dari persepsi pola asuh [The tendency of Cinderella complex found in female students in terms of the parenting perception]. Jurnal RAP (Riset Aktual Psikologi Universitas Negeri Padang), 8(2), 211-222.

Otanjac, M. I. (2016). Students with language learning disabilities and difficulties in a foreign language classroom. Specijalna edukacija i rehabilitacija, 15(4), 461-474. https://doi. org/10.5937/specedreh15-12071

Pagliaro, M. M. (2011). Educator or bully? Managing the 21st century classroom. London: Rowman \& Littlefield Publishers, Inc.

Pappamihiel, N. E., Nishimata, T., \& Mihai, F. (2008). Timed writing and adult English language learners: An investigation of first language use in invention strategies. Journal of Adolescent \& Adult Literacy, 51(5), 386-394. 
Perras, C. (2014). Language acquisition difficulty or learning disability? How to differentiate and support English language learners with a learning disability. https://www.ldatschool.ca/ language-acquisition-difficulty-or-learning-disability/

Reeves, S., Peller, J., Goldman, J., \& Kitto, S. (2013). Ethnography in qualitative educational research: AMEE Guide No. 80. Medical Teacher, 35, 1365-1379. https://doi.org/10.3109/014 2159X.2013.804977

Reyes, L. V. T. (2015). Research on the difficulties that adults encounter in learning a foreign language at (UASD, Santo Domingo) in this semester 2015. [Bachelor Thesis], University of Santo Domingo, Bonao, Monseñor Nouel, Dominican Republic. https://files.eric.ed.gov/ fulltext/ED592539.pdf

Saha, S., \& Safri, T. S. (2019). Cinderella complex: Theoretical roots to psychological dependency complex in women. The International Journal of Indian Psychology, 3(3), 118-122.

Sanford, K. L. (2015). Factors that affect the reading comprehension of secondary students with disabilities. [Doctoral Dissertation], University of San Francisco, San Francisco, USA. https:// repository.usfca.edu/cgi/viewcontent.cgi?article $=1125 \&$ context $=$ diss

Saritha, K. (2016). Rubric for English language teaching research. Research Journal of English Language and Literature, 4(2), 725-731.

Shatrova, Z., Mullings, R., Blažejová, S., \& Üstünel, E. (2017). English speaking assessment: Developing a speaking test for students in a preparatory school. International Journal of English Language Teaching, 5(3), 27-40.

Shen, M-. Y \& Chiu, T-Y. (2019). EFL learners' English speaking difficulties and strategy use. Education and Linguistics Research, 5(2), 88-102. https://doi.org/10.5296/elr.v5i2.15333

Suldo, S, Thalji, A, \& Ferron, J. (2011). Longitudinal academic outcomes predicted by early adolescents' subjective well-being, psychopathology, and mental health status yielded from a dual factor model. The Journal of Positive Psychology, 6(1), 17-30. https://doi.org/10.1080/1 $\underline{7439760.2010 .536774}$

Sumekto, D. R., Taufiqulloh, T., Setyawati, H., Hikmah, S., \& Ghozali, I. (2021). Understanding the paralinguistic features disclosure depicted in the lecturer's visual modes of writing class instruction. 3L: Language, Linguistics, Literature, 27(4), 173-192. https://doi. org/10.17576/3L-2021-2704-13

Sumekto, D. R., Setyawati, H., Tukiyo, \& Warsito, R. (2020). The determinants of lecturers' classroom management as depicted in their teaching performance. Pedagogika, 139(3), 136-156. https://doi.org/10.15823/p.2020.139.7

Sumekto, D. R., \& Setyawati, H. 2020. Revealing lecturer's paralinguistic attribution: How the visual manner contributes to students' non-cognitive skills. Indonesian Journal of Applied Linguistics, 9(3), 559-571. https://doi.org/10.17509/ijal.v9i3.23206

Suwanarak, K. (2019). Use of learning strategies and their effects on English language learning of Thai adult learners. 3L: Language, Linguistics, Literature, 25(4), 99-120. https://doi. org/10.17576/3L-2019-2504-07 
The National Education Association. (2015). How educators can advocate for English language learners. https-//www.colorincolorado.org/sites/default/files/ELL AdvocacyGuide2015.pdf

Turner, J. E., Li, B., \& Wei, M. (2021). Exploring effects of culture on students' achievement motives and goals, self-efficacy, and willingness for public performances: The case of Chinese students' speaking English in class. Learning and Individual Differences, 85, 113-124. https:// doi.org/10.1016/j.lindif.2020.101943

Victoria State Government. (2019). Learning difficulties information guide. Melbourne: State of Victoria (Department of Education and Training). https://www.education.vic.gov.au/ Documents/school/teachers/teachingresources/discipline/english/reading/literacy-guide.pdf

Xu, H., Zhang., Z., Wu, L., \& Wang, C. J. (2019). The Cinderella complex: Word embeddings reveal gender stereotypes in movies and books. PLOS ONE, 14(11), 1-18. https://doi.org/10.1371/ journal.pone.0225385

Zarra, E. J. (2016). Addressing appropriate and inappropriate teacher-student relationships: A secondary education professional development model. CLEARvoz Journal, 3(2), 15-29. https:// journals.sfu.ca/cvj/index.php/cvj/article/view/26

\title{
Ocha lanko paskaitas: besimokančio suaugusiojo, turinčio Pelenès sindroma, patirtis
}

\author{
Didik Rinan Sumekto ${ }^{1}$, Ery Pranawa ${ }^{2}$, Taufiqulloh ${ }^{3}$, Imam Ghozali ${ }^{4}$, Suhud Eko Yuwono
}

1 Sarjanawiyata Tamansiswa universitetas, Švietimo magistrantūros direktoratas, Anglų kalbos ugdymo katedra, Jl. Kusumanegara Nr.157, Daerah Istimewa, ID - 55165, Jogjakarta Indonezija, didikrinan@ustjogja.ac.id

2 Widya Dharma universitetas, Indonezijos švietimo katedra, Jl. Ki Hajar Dewantara, Klatenas Utara, ID - 57438, Klatenas, Jawa Tengah, Indonezija, erry@unwidha.ac.id

3 Pancasakti universitetas, Anglų kalbos ugdymo katedra, Jl. Halmahera KM. 1, JavaTengah, ID - 52121 Tegal, Indonezija, taufiqkayla@upstegal.ac.id

4 Sarjanawiyata Tamansiswa universitetas, Švietimo magistrantūros direktoratas, Anglų kalbos ugdymo katedra, Jl. Kusumanegara Nr.157, Daerah Istimewa, ID - 55165, Jogjakarta, Indonezija, ghozali@ustjogja.ac.id

5 Widya Dharma universitetas, Anglų kalbos ugdymo katedra, Jl. Ki Hajar Dewantara, Klatenas Utara, ID - 57438, Klatenas Jawa Tengah, Indonezija, yuwono@unwidha.ac.id

\section{Santrauka}

Pastaruoju metu nedaug suaugusiųjų, turinčių Pelenès sindromą, lanko paskaitas universitetuose. Šiame tyrime nagrinejjamas vienas toks atvejis. Tiriama anglų kalbos bakalauro studijų 22 metų studentė, vardu Ocha (slapyvardis), kuri studijuoja Widya Dharma universitete, Klatene, Indonezijoje, ir jos paskaitų lankymas.

Šiame tyrime pagrindinis dėmesys skiriamas Ochos veikliajai sąveikai ir kontekstualiai veiklai internetineje ir realioje mokymosi aplinkoje. Atlikta informacijos sintezè. Kaip duomenų rinkimo metodai naudojami interviu, stebejimas ir filmuota medžiaga. 
Tyrimas atskleidžia, kad Ocha yra suaugusi besimokančioji, turinti Pelenės sindromą. Nors ši studentè pasižymi didele motyvacija lankyti anglų kalbos paskaitas, tačiau ji susiduria su tam tikrais sunkumais tiek internetinejje, tiek realioje mokymosi aplinkoje - jos komunikaciniai gebejjimai, žodynas, gramatika ir tarimas yra riboti. Ochos elgesys skiriasi nuo kitų studentų dèl bendravimo stokos, neišmanymo, kaip tai daryti, uždarumo, egocentriškumo, priklausomybès ir užsispyrimo.

Kalbant apie kontekstualią veiklą ankstesnis Ocha mokymasis yra susijęs su asmenybès bruožais, didejančia ir mažejjančia motyvacija, savigarba, nerimu ir socialine patirtimi. Šis tyrimas rodo augančią bendravimo ir santykių pastangų svarbą, siekiant susieti Ochos mokymosi praktiką su jos grupès draugų praktika bei siekiant suprasti jos polinkị ị tarpusavio adaptaciją.

Esminiai žodžiai: veiklioji squveika, Pelenès sindromas, kontekstuali veikla. 